\title{
Properties of Concrete made with Waste Clay Brick as Sand Incorporating $\mathrm{Nano}_{\mathrm{SiO}_{2}}$
}

\author{
Davoud Tavakoli ${ }^{*}$, Ali Heidari ${ }^{2}$ and Sasan Hayati Pilehrood ${ }^{3}$ \\ 'Young Researchers and Elite Club, Shahrekord Branch, Islamic Azad University, Shahrekord, Iran; \\ tavakoli.d@gmail.com \\ ${ }^{2}$ Department of Civil Engineering, University of Shahrekord, Shahrekord, Iran \\ ${ }^{3}$ Maybod Branch, Islamic Azad University, Yazd, Iran
}

\begin{abstract}
The present study aims to investigate the use of clay bricks in concrete preparation. In the first phase of the study, the clay bricks as waste materials from building remains were collected and ground by jaw mills and finally graded in the range of standard sand. The first experiments like XRF, water absorption, and unit weight were then carried out on the materials. After that, some samples with substitution percents of zero to one hundred from waste bricks as sand were made and the new concrete parameters such as compressive strength, water absorption and unit Weight were examined. In the second phase, nano $\mathrm{SiO}_{2}$ in all mixes from the brick waste materials were replaced for the cement and then the experiments of compressive strength and water absorption were done on the samples that contained nano $\mathrm{SiO}_{2}$ and waste clay bricks. The results clearly revealed that, in light of some positive effect such as a reduction in the concrete unit weight and recycling the waste materials and also the minimum reduction of compressive strength, using brick waste materials may be considered a suitable choice in concrete especially in areas close to brick furnaces. Furthermore, nano $\mathrm{SiO}_{2}$ can improve the strength and durability of concrete. Conclusively, using waste bricks can be an effective measure in sustainable development.
\end{abstract}

Keywords: Aggregate, Concrete, Nano $\mathrm{SiO}_{2}$, Sustainable Development, Waste Clay Brick

\section{Introduction}

Concrete, as a constructive material becomes costlier due to raw material shortage. Therefore, developing novel technologies in production concrete is of great importance. Furthermore, large amount of wastage is produced during reconstruction of old building. Most of these wastages are not reusable or if they are, their recycling leads to wasting energy and pollution which in turn increases the environmental risk. Moreover, there is a need to develop strategy to achieve the twin aim of removing the wastage material and also obtaining the positive qualities of concrete $^{1-4}$.

Recently, using new materials in concrete has become prevalent. Such materials are commonly used as a substation for aggregate or as a substitute for cement in concrete. This substitution is used as a strategy to help environment, reducing in budget and improving the features of concrete.
Various studies have been achieved on using waste materials in concrete. Using glass, plastic, and ceramic tile are the examples of using waste materials in concrete $e^{5-8}$. These waste materials can replace cement or aggregates in concrete. Some materials have the features of being used as pozzolan and some others can be used just as fillers or aggregates. Besides, using the waste materials of clay, brick has also been studied recently and usually positive impacts have been reported ${ }^{9-12}$.

The waste materials of clay bricks are usually come in different ways. Some are created in factories during and after the production process as a result of human mistakes, inappropriate materials, or a mistake in production process, some others are formed in transportation and distribution stage and finally a large part of waste materials are formed as a result of destroying buildings. The amount of waste materials may account to millions of tons annually. The nature of these materials is in a way that it is impossible 
to reuse them in the production cycle and therefore they are practically useless and as one type of building trash can pollute and damage environment. Therefore, finding strategies to use them can be rewarding.

In a study, using brick aggregates in producing paving blocks has been investigated from which it has been concluded that using 25 percent of brick waste materials to produce paving blocks is acceptable ${ }^{13}$. In another study, using clay brick waste materials along with concrete waste materials as aggregates in concrete were studied ${ }^{14}$. Similarly, an investigation on the use of brick waste materials in light weight foamed concrete concluded that with the use of 25 percent of waste materials a suitable unit weight and resistance ${ }^{15}$ could be reached. In another study the use of the powder of clay brick waste materials as a substitution of cement were investigated. In this study the ASR were also dealt with. It reported that using brick waste materials as aggregate usually decrease the resistance and durability properties of concrete ${ }^{16}$. However due to their being waste materials, their use has been reported to be positive.

On the other hand, the usage of nano $\mathrm{SiO}_{2}$ in concrete has been increasing in recent years. The positive effects of using nano $\mathrm{SiO}_{2}$ on the mechanical properties of concrete and cement mortar have been shown by recent studies $^{17-20}$. Moreover, the mechanical properties of concrete were significantly improved with the use of nano- $\mathrm{SiO}_{2}$ and pozzolan together ${ }^{21,22}$.

However, no comprehensive study has yet done in which the use of waste clay brick sand and nano $\mathrm{SiO}_{2}$ simultaneously. Therefore, in this experimental study, the effects of using simultaneous nano $\mathrm{SiO}_{2}$ as pozzolan and waste brick clay as sand were studied by using 1 percent nano $\mathrm{SiO}_{2}$ and 0 to 100 percent waste clay brick.

\section{Materials and Mix Proportion}

\subsection{Aggregates}

The waste clay brick used in this study was obtained from recycled clay brick supplied by Gachsaran brick Company in Iran. Cracked pieces of clay brick were crushed by a jaw crusher. The clay brick aggregate is shown in Figure 1.

The gradation of aggregates affects both fresh and hardened concretes. The sieve analysis of this crushed aggregates have been performed according to ASTM C136. The gradations of clay brick aggregate and natural aggregate are shown in Figure 2 and Table 1.

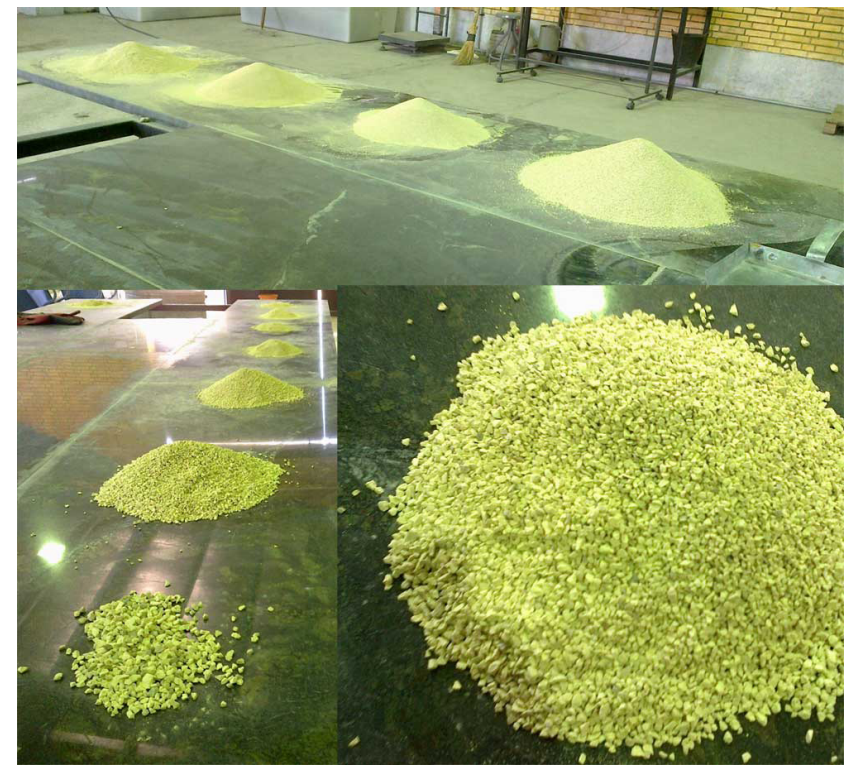

Figure 1. Clay brick aggregate.

Clay brick Sands were sieved in such a way that their grading are exactly compatible with the natural used aggregate in concrete, this compatibility causes that the error created by the grading differences in the properties of concrete become minimized. The diagram of grading of clay brick sand and natural ones should be exactly compatible.

The chemical compositions of clay brick powder were analyzed, and the results obtained are reported in Table 2. Table 2 also indicates that the intended materials are in ideal conditions in terms of chemical components all of which are beneficial for concrete. Having high $\mathrm{CaO}$ and silica in brick may improve the performance of cement in concrete. Further, the total alkali $(\mathrm{Na} 2 \mathrm{O}+0.65 \mathrm{~K} 2 \mathrm{O})$ is 2.21 percent. Considering above-mentioned features, it can be concluded that brick has the capability of being used in concrete as aggregate.

In Table 3, the compulsory necessities of harmful materials based on ASTM standards and the brick aggregate features have been compared. Considering Table 3 it becomes apparent that all standards have been reserved Except for the sulfate maximum one. The code, in order to control the amount of sulfate in concrete, has allowed using the aggregate provided that the sulfate amount doesn't exceed the maximum allowed amount. From Table 3 it can also be observed that the aggregates are in standard range.

The natural sand and the coarse aggregate used in the concrete were crushed limestone aggregates. The gradations of aggregates are shown in Figure 2 and Table 1. Physical properties of the natural aggregates are shown in Table 4. 

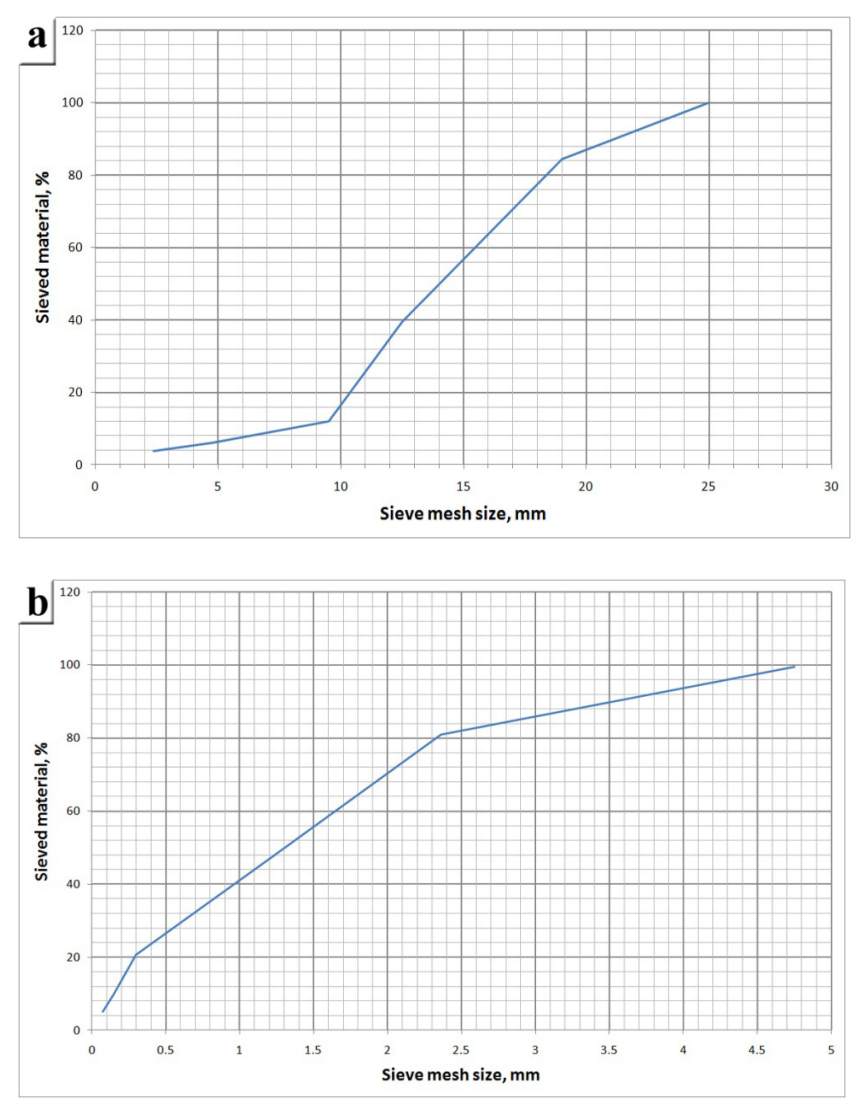

Figure 2. Gradation of both clay brick and natural aggregates: a) coarse aggregate b) sand.

Table 1. Gradation of aggregates used in concrete

\begin{tabular}{lcc}
\hline \multirow{2}{*}{ Sieve size, $\mathrm{mm}$} & \multicolumn{2}{c}{ Cumulative percentage passing } \\
\cline { 2 - 3 } & Sand & Coarse aggregate \\
\hline 25 & 100 & 100 \\
19 & 100 & 84.4 \\
12.5 & 100 & 39.45 \\
9.5 & 100 & 12.075 \\
4.75 & 99.5 & 6.15 \\
2.36 & 80.97 & 3.85 \\
1.18 & 46.27 & - \\
0.6 & 29.49 & - \\
0.3 & 20.75 & - \\
0.15 & 9.86 & - \\
0.075 & 5.03 & - \\
\hline
\end{tabular}

Table 2. Chemical analysis of the clay brick

\begin{tabular}{cc}
\hline amount & Materials \\
\hline $46.52 \%$ & $\mathrm{SiO}_{2}$ \\
$10.62 \%$ & $\mathrm{Al}_{2} \mathrm{O}_{3}$ \\
$4.29 \%$ & $\mathrm{Fe}_{2} \mathrm{O}_{3}$ \\
$24.48 \%$ & $\mathrm{CaO}$ \\
$1.02 \%$ & $\mathrm{Na}_{2} \mathrm{O}$ \\
$1.84 \%$ & $\mathrm{~K}_{2} \mathrm{O}$ \\
$8.56 \%$ & $\mathrm{MgO}$ \\
$0.514 \%$ & $\mathrm{TiO}_{2}$ \\
$0.079 \%$ & $\mathrm{MnO}$ \\
$0.199 \%$ & $\mathrm{P}_{2} \mathrm{O}_{5}$ \\
$0.895 \%$ & $\mathrm{SO}_{3}$ \\
$0.66 \%$ & $\mathrm{LOI}_{108 \mathrm{ppm}}$ \\
\hline
\end{tabular}

Table 3. Limits for Deleterious Substances in Fine Aggregate for Concrete

\begin{tabular}{lcc}
\hline Properties & clay brick & ASTM \\
\hline $\begin{array}{l}\text { Clay lumps and friable } \\
\text { particles }\end{array}$ & 2.6 & 3 \\
Material finer than $75-\mu \mathrm{m}$ & 4.82 & 5 \\
Coal and lignite & 0 & 1 \\
Water-soluble sulfate & 0.89 & 0.4 \\
Water-soluble chloride & 0.01 & 0.04 \\
\hline
\end{tabular}

Table 4. Properties of aggregates

\begin{tabular}{lccc}
\hline Property & $\begin{array}{c}\text { natural } \\
\text { sand }\end{array}$ & $\begin{array}{c}\text { clay brick } \\
\text { sand }\end{array}$ & $\begin{array}{c}\text { Coarse } \\
\text { aggregate }\end{array}$ \\
\hline Density $\left(\mathrm{g} / \mathrm{cm}^{3}\right)$ & 2.6 & 2.03 & 2.55 \\
Fineness modules & 3.1 & 3.1 & - \\
Water absorption (\%) & 2 & 12 & 0.2 \\
Maximum size (millimeter) & - & - & 25 \\
$\begin{array}{l}\text { Aggregate abrasion value, } \\
\text { Los Angeles (\%) }\end{array}$ & - & - & 26.43 \\
\hline
\end{tabular}

The water absorption, particle size distribution, density and fineness modulus of the aggregates were specified following the test methods described in ASTM. Some properties of the aggregates are shown in Table 4. 


\subsection{Water}

The water used in the concrete was taken from the city of Shahrekord in Iran. The PH, sulphate content and chloride content of the water used in the study were $7.8,29$ $\mathrm{mg} / \mathrm{lit}$ and $40 \mathrm{mg} / \mathrm{lit}$, respectively.

\subsection{Cement}

Locally available Portland cement (ASTM Type II) was used. The specifications of the cement are shown in Table 5.

\subsection{Nano $\mathrm{SiO}_{2}$}

A cement paste is compound of small grains of hydrated calcium silicate gels, nano-sized particular pores, capillary pores, and large crystals of hydrated products. Thus, there should be room for nano-phase materials to fill the pores of the cement paste. Amorphous nano-scale silica, which is the main component of a pozzolan, reacts with calcium hydroxides formed by the hydration of calcium silicates. The rate of the pozzolanic reaction is commensurate with the value of the Blaine fineness ${ }^{18}$. Thus, nano- $\mathrm{SiO}_{2}$ was

Table 5. Properties of cement

\begin{tabular}{|c|c|c|c|}
\hline $\begin{array}{l}\text { Chemical } \\
\text { properties }\end{array}$ & Percent & $\begin{array}{c}\text { Physical } \\
\text { properties }\end{array}$ & Value \\
\hline $\mathrm{SiO}_{2}$ & 21.8 & Initial Setting & 95 (min) \\
\hline $\mathrm{Al}_{2} \mathrm{O}_{3}$ & 5.1 & $\begin{array}{c}\text { Final } \\
\text { Setting,(min) }\end{array}$ & $150(\min )$ \\
\hline $\mathrm{Fe}_{2} \mathrm{O}_{3}$ & 3.9 & Fineness(blain) & $\geq 2900(\mathrm{~cm} 2 / \mathrm{g})$ \\
\hline $\mathrm{CaO}$ & 64.8 & $\begin{array}{l}\text { Autoclave } \\
\text { expansion }\end{array}$ & $\leq 0.15$ (percent) \\
\hline $\mathrm{MgO}$ & $\leq 1.7$ & $\begin{array}{c}3 \text { Days } \\
\text { Compressive } \\
\text { strength }\end{array}$ & $\geq 190(\mathrm{Mpa})$ \\
\hline $\mathrm{CL}$ & $\leq 0.03$ & $\begin{array}{c}7 \text { Days } \\
\text { Compressive } \\
\text { strength }\end{array}$ & $\geq 320(\mathrm{Mpa})$ \\
\hline $\mathrm{SO}_{3}$ & $\leq 2.0$ & $\begin{array}{l}28 \text { Days } \\
\text { Compressive } \\
\text { strength }\end{array}$ & $\geq 490(\mathrm{Mpa})$ \\
\hline L.O.I & $\leq 1.3$ & & \\
\hline $\operatorname{LnR}$ & $\leq 0.65$ & & \\
\hline F.CaO & $\leq 1.1$ & & \\
\hline $\mathrm{C}_{3} \mathrm{~A}$ & $\leq 7.5$ & & \\
\hline Total Alkali & $\leq 0.7$ & & \\
\hline
\end{tabular}

bought from WACKER chemical company, and its main properties are shown in Table 6.

\subsection{Mix Proportion}

The present investigation studied the partial replacement of natural aggregate by clay brick (phase A) and reduced the cement content by adding several combinations of a clay brick and nano- $\mathrm{SiO}_{2}$ (phase $\mathrm{B}$ ). The mixture is designed according to ACI-211. At the beginning of the mixture design, the binder content $(320 \mathrm{~kg} / \mathrm{m} 3)$ and water-cement ratio (0.5) were chosen to be constant.

In phase $\mathrm{A}$, mixes were made with waste clay brick replacing $0,25,50,75$ and 100 percent by weight of the sand.

The objective was to produce pozzolanic concretes using clay brick sand and nano- $\mathrm{SiO}_{2}$. Accordingly, concrete mixtures using different mix proportions and several combinations of clay brick sand and nano- $\mathrm{SiO}_{2}$ were initially performed. Eight high strength concrete mixes were optimized and used in the current study. Mixes contained 0.5\% and $1 \%$ nano- $\mathrm{SiO}_{2}$ and different proportions of ground ceramic powder $(10 \%, 15 \%, 20 \%$ and $25 \%)$ by weight of cement. The concrete mixture proportions in phase A are shown in Table 7 and in phase B are shown in Table 8.

\section{Mix Design}

The concrete mixtures were mixed in accordance with ASTM C 192 in 120 litre drum mixer. The workability of the fresh concrete was measured with a standard slump cone using the slump test according to ASTM C 143. The test specimens were cast in steel cubic moulds $(150 \times$ $150 \times 150)$ and compacted on a vibrating table. After

Table 6. Properties of nano- $\mathrm{SiO}_{2}$

\begin{tabular}{lc}
\hline Properties & Characteristics \\
\hline Surface area $\left(\mathrm{m}^{2} / \mathrm{g}\right)$ & $200 \pm 30$ \\
$\mathrm{SiO} 2$ content $($ percent$)$ & $>99.8$ \\
Tamped bulk density $(\mathrm{g} / \mathrm{l})$ & Approx. 40 \\
Moisture (percent) & $<1.5$ \\
Loss on ignition (percent) & $<1.5$ \\
$\mathrm{PH}$ value $(4 \%$ dispersion in water) & $3.8-4.3$ \\
$\mathrm{Al} 2 \mathrm{O} 3$ content (percent) & $<0.05$ \\
$\mathrm{Fe} 2 \mathrm{O} 3$ content (percent) & $<0.005$ \\
$\mathrm{TiO} 2$ content (percent) & $<0.003$ \\
\hline
\end{tabular}


Table 7. Concrete mixture proportions (phase A)

\begin{tabular}{lrrrrr}
\hline \multirow{2}{*}{ Properties } & \multicolumn{5}{c}{ Mixture name } \\
\cline { 2 - 6 } & C & CB25 & CB50 & CB75 & CB100 \\
\hline Cement, $(\mathrm{kg} / \mathrm{m} 3)$ & 320 & 320 & 320 & 320 & 320 \\
Natural sand, $(\mathrm{kg} / \mathrm{m} 3)$ & 840 & 630 & 420 & 210 & 0 \\
Clay brick sand, (kg/m3) & 0 & 210 & 420 & 630 & 840 \\
$\begin{array}{l}\text { Natural coarse aggregate, } \\
(\mathrm{kg} / \mathrm{m} 3)\end{array}$ & 1040 & 1040 & 1040 & 1040 & 1040 \\
Water, $(\mathrm{kg} / \mathrm{m} 3)$ & 160 & 160 & 160 & 160 & 160 \\
\hline
\end{tabular}

Table 8. Concrete mixture proportions (phase B)

\begin{tabular}{lrrrcc}
\hline \multirow{2}{*}{ Properties } & \multicolumn{5}{c}{ Mixture name } \\
\cline { 2 - 6 } & C & CB25N1 & CB50N1 & CB75N1 CB100N1 \\
\hline $\begin{array}{l}\text { Cement, } \\
(\mathrm{kg} / \mathrm{m} 3)\end{array}$ & 320 & 316.8 & 316.8 & 316.8 & 316.8 \\
$\begin{array}{l}\text { Natural } \\
\text { sand, (kg/m3) }\end{array}$ & 840 & 630 & 420 & 210 & 0 \\
$\begin{array}{l}\text { Clay brick } \\
\text { sand, (kg/m3) }\end{array}$ & 0 & 210 & 420 & 630 & 840 \\
$\begin{array}{l}\text { Natural } \\
\text { coarse aggregate, }\end{array}$ & 1040 & 1040 & 1040 & 1040 & 1040 \\
(kg/m3) & & & & & \\
$\begin{array}{l}\text { nano SiO2 } \\
\text { Water, (kg/m3) }\end{array}$ & 160 & 160 & 160 & 160 & 160 \\
\hline
\end{tabular}

approximately 24 hours, the specimens were removed from the moulds. The concrete specimens were cured in lime-saturated water at $21^{\circ} \mathrm{C}$ in cure tanks until the time of testing. Casting, compaction, and curing were accomplished according to ASTM C 192.

For each mix, cubic samples were tested to determine the compressive strengths at 7 and 28 days of curing. A 2000-kN capacity uniaxial compressive testing machine was used to compressive strength test. The water absorption test according to ASTM C 642 was conducted at the end of the 28th day. The compressive strength, specific Wight and water absorption for each mixture was obtained from average of three cubic specimens.

\section{Results and Discussion}

In the first phase of the study, the impact of brick waste materials as a substitution for sand was investigated. The pertaining findings have been shown in the following way: the slump findings in Table 9, the compressive strength findings in Figure 3, the unit weight findings in Figure 4, and the water absorption findings in Figure 5.

In presenting the findings, the mean of samples has been brought. Table 9 shows that as the clay brick sand decreases, the slump increases. This decrease can be due to the shape and structure of the clay brick. Therefore, it can be concluded that because of the slight reduction, there is no significant difference between the ordinary concrete and the clay brick concrete and it is more possible to use in the relative construction site without using plasticizer or more water. In case where the clay brick sand is lower than 50 percent, the slight reduction can be ignored.

Table 9. Slump value (phase A)

\begin{tabular}{lccccc}
\hline sample & C & CB25 & CB50 & CB75 & CB100 \\
slump $(\mathrm{mm})$ & 50 & 45 & 45 & 40 & 35 \\
\hline
\end{tabular}

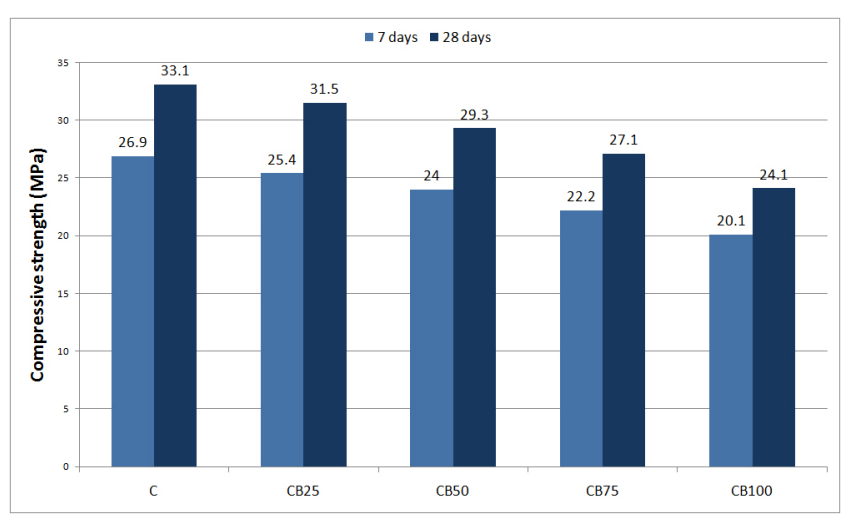

Figure 3. Compressive strength (phase A).

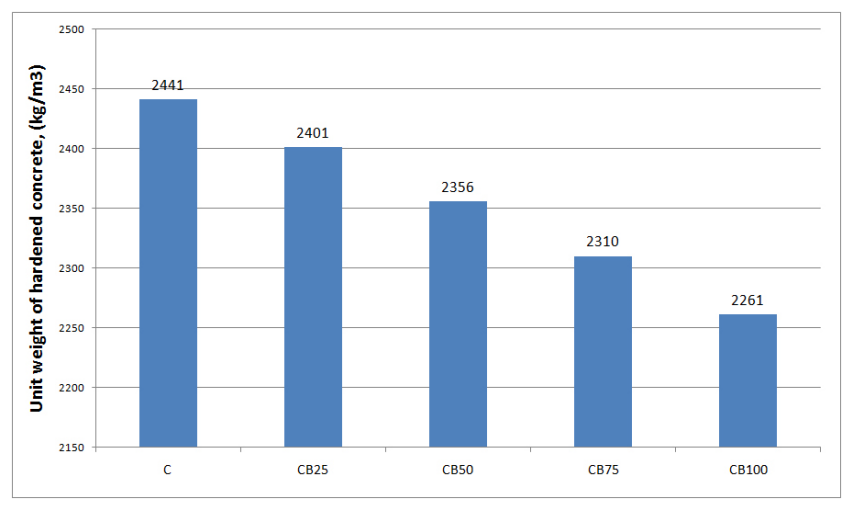

Figure 4. Unit weight of hardened concrete (phase A). 


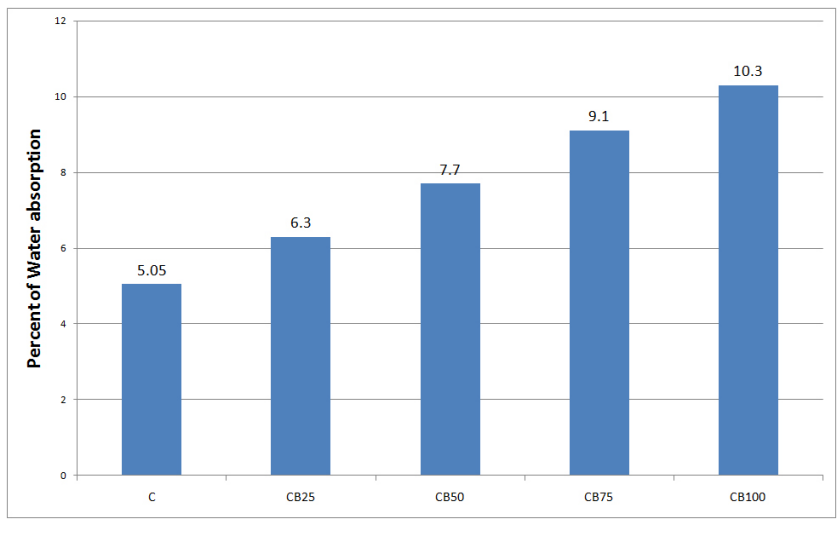

Figure 5. Water absorption (phase A).

Figure 3 shows the samples compressive strength. It shows that the compressive strength decrease as the brick sand increases sand the maximum of this reduction is for the 100 percent sample which has 27 percent of compressive strength reduction. This reduction for samples of 75,50 and 25 percent is $18.1,11.5$, and 4.8 respectively. The reduction can be ignored for the 25 percent sample. Besides, the reduction for more than 25 percent doesn't seem to be suitable. The strength reduction as the brick sand increases is due to the less strength of brick sand in comparison with natural sand.

Figure 4 shows the samples unit weight. The unit weight decreases with the increase of brick sand as compared with natural sand. In the case of using only 25 percent of brick sand in the concrete structure, about $40 \mathrm{~kg}$ reduction in weight will be resulted that lead to a lighter structure for a more suitable design.

Figure 5 shows the water absorption percentage. As the brick increases, the water absorption also increases. These increases can be due to the more absorption of water compared with the natural sand and the created pore can be because of the use of such a material. This increase is trivial in CB25 but the water absorption increase for the CB100 sample is more remarkable than the control sample. High water absorption in different conditions may result in the damage to concrete in long term and hence decrease the concrete durability.

In the second phase, given the durability and strength properties reduction in the concrete with clay brick waste materials, nano $\mathrm{SiO}_{2}$ was used as a substitute for cement to improve the concrete features, the related findings are in figures 6 (compressive strength) and 7 (water absorption).
Figure 6 shows that using 1 percent of nano $\mathrm{SiO}$ increases compressive strength considerably in the early stages. Figure 7 illustrates that adding nano- $\mathrm{SiO}_{2}$ to concrete leads to much lower water absorption compared to control concrete.

Water absorption is a signal of the concrete durability properties and the present study findings reveal that adding nano $\mathrm{SiO}_{2}$ can improve the concrete by improving the compressive strength and decreasing the water absorption. One of the reasons is the filling impact of the particles. That is, the nano $\mathrm{SiO}_{2}$ particles, due to their size and surface stickiness, are placed among C-S-H and fill the spaces. This by itself leads to the unity of C-S-H and its durability. Besides, this properties of nano $\mathrm{SiO}_{2}$ increases the hydration reaction temperature and therefore increases the acceleration of strength gain. Other reason for the increase of strength can be the nucleation. That is, nano $\mathrm{SiO}_{2}$ creates some nucleus to develop the cement hydration products finally. These materials play

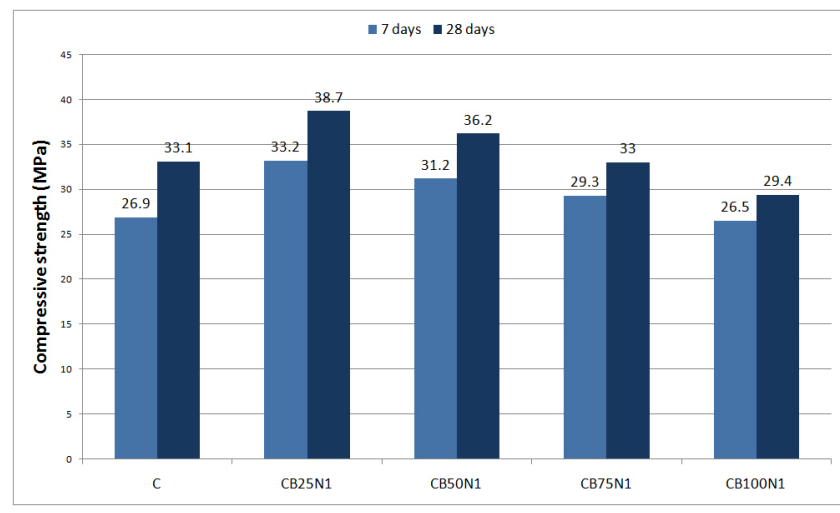

Figure 6. Compressive strength (phase B).

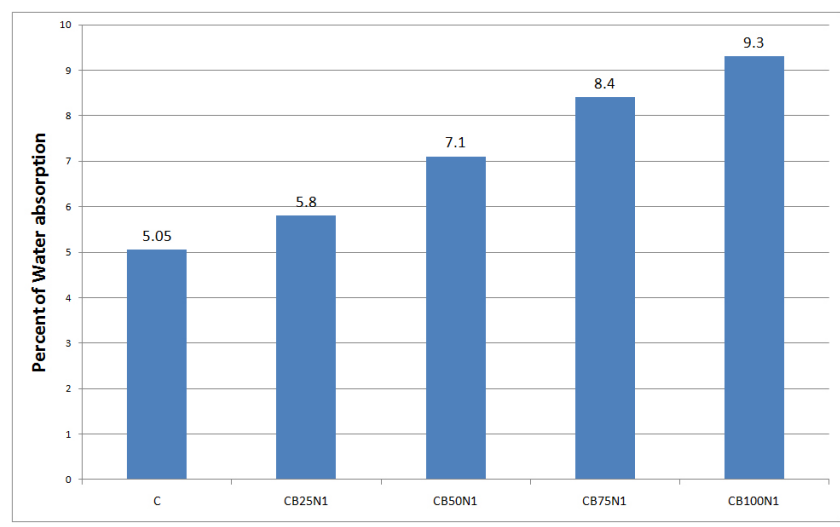

Figure 7. Water absorption (phase B). 
the role of bones against the cement gel which has a great role in the concrete strength.

\section{Conclusion}

There is no significant problem to use brick as sand in optimal percents in terms of mechanical properties like compressive strength. However, because of the higher water absorption, a long observation is necessary. It is recommended to use brick sand up to 25 percent. Using nano $\mathrm{SiO}_{2}$ along with brick waste materials improves the durability and strength properties of concrete and neutralizes the negative effects of waste clay brick. Using only 1 percent of nano $\mathrm{SiO}_{2}$ can cover the negative effects on compressive strength of using 75 percent of clay brick sand.

Wasted bricks may pollute the environment and make the appearance of suburbs dirty. Therefore using such a material can be a better approach. Besides, because it has no negative effect on the concrete, it can also help the construction process in terms of budget. The combination of nano $\mathrm{SiO}_{2}$ and brick waste materials improves the durability and strength of concrete and also the reduction of its unit weight.

\section{References}

1. Mehta PK. Reducing the environment impact of concrete. Concrete can be durable and environmentally friendly. Concrete International. 2001; 10:61-6.

2. Mohanraj EK, Kandasamy S, Rajkumar N. Study on concrete using waste materials by partial replacement of aggregates to reduce global warming gases. Indian Journal of Science and Technology. 2011; 4(3):159-62.

3. Bhikshma V, Manipal K. Study on mechanical properties of recycled aggregate concrete containing containing steel fibers. Asian Journal of Civil Engineering (Building and Housing). 2012; 13(2):154-64.

4. Nagabhushana, Bai HS. Use of crushed rock powder as replacement of fine aggregate in mortar and concrete. Indian Journal of Science and Technology. 2011; 4(8):917-22.

5. Topcu BI, Sengel S. Properties of concretes produced with waste concrete aggregate. Cement and Concrete Research. 2004; 34:1307-12.

6. Federico L, Chidiac S. Waste glass as a supplementary cementitious material in concrete Critical. Cement \& Concrete Composites. 2009; 31:606-10.

7. Ismail Z, AL-Hashmi E. Use of waste plastic in concrete mixture as aggregate replacement review of treatment methods. Waste Management. 2008; 28:2041-7.
8. Tavakoli D, Heidari A, karimian M. Properties of concretes produced with waste ceramic tile aggregate. Asian journal of civil engineering (BHRC). 2013; 14(3):369-82.

9. Khaloo AR. Crushed Tile Coarse Aggregate Concrete. Cement, Concrete and Aggregates. 1995; 17:119-25.

10. Khalaf FM. Using Crushed Clay Brick as Aggregate in Concrete. Journal of Materials in Civil Engineering. 2006; 18:518-26.

11. Ge Z, Gao Z, Sun R, Zheng L. Mix design of concrete with recycled clay-brick-powder using the orthogonal design method. Construction and Building Materials. 2012; 31:289-93.

12. Bektas F, Wang K, Ceylan H. Effects of crushed clay brick aggregate on mortar durability. Construction and Building Materials. 2009; 23:1909-14.

13. Jankovic K, Nikolic D, Bojovic D. Concrete paving blocks and flags made with crushed brick as aggregate. Construction and Building Materials. 2012; 28(1):659-63.

14. Yang J, Du Q, Bao Y. Concrete with recycled concrete aggregate and crushed clay bricks. Construction and Building Materials. 2011; 25(4):1935-45.

15. Ibrahim MN, Salehuddin S, Amat CR, Rahim LN, Izhar NTT. Performance of Lightweight Foamed Concrete with Waste Clay Brick as Coarse Aggregate. APCBEE Procedia. 2013; 5:497-501.

16. Bektas F, Wang K. Performance of ground clay brick in ASR-affected concrete: Effects on expansion, mechanical properties and ASR gel chemistry. Cement and Concrete Composites. 2012; 34(2):273-8.

17. Byung WJ, Kim $\mathrm{CH}$ and $\mathrm{Lim} \mathrm{JH}$. Investigations on the development of powder concrete with nano- $\mathrm{SiO}_{2}$ particles. KSCE Journal of Civil Engineering. 2008; 11(1):37-42.

18. Qing Y, Zenan Z, Deyu K, Rongshen Ch. Influence of nano$\mathrm{SiO}_{2}$ addition on properties of hardened cement paste as compared with silica fume. Construction and Building Materials. 2007; 21:539-45.

19. Tao Ji. Preliminary study on the water permeability and microstructure of concrete incorporating nano- $\mathrm{SiO}_{2}$. Cement and Concrete Research. 2005; 35:1943-7.

20. Sotoudeh MH, Jalal M. Effects of Waste Steel Fibers on Strength and Stress-strain Behavior of Concrete Incorporating Silica Nano powder. Indian Journal of Science and Technology. 2013; 6(11):5411-7.

21. Heidari A, Tavakoli D. A study of the mechanical properties of ground ceramic powder concrete incorporating nano$\mathrm{SiO}_{2}$ particles. Construction and Building Materials. 2013; 38:255-64.

22. Tavakoli D, Heidari A. Properties of concrete incorporating silica fume and nano- $\mathrm{SiO}_{2}$. Indian Journal of Science and Technology. 2013; 6(1):108-12. 